\title{
Depression and anxiety in the practice of cardiology
}

\author{
Dominika Dudek ${ }^{1,2,3}$, Rafał Jaeschke ${ }^{1,2}$, Krzysztof Styczeńn ${ }^{1,3}$, Maciej Pilecki ${ }^{1,4}$ \\ ${ }^{1}$ Adult Psychiatry Department, University Hospital, Krakow, Poland \\ 2Department of Affective Disorders, Department of Psychiatry, Jagiellonian University, Collegium Medicum, Krakow, Poland \\ ${ }^{3}$ Institute of Pharmacology, Polish Academy of Sciences, Krakow, Poland \\ ${ }^{4}$ Department of Psychiatry, Jagiellonian University, Collegium Medicum, Krakow, Poland
}

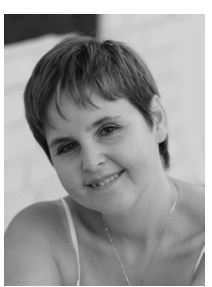

\section{INTRODUCTION}

Depression raises significant public health concerns. According to the National Comorbidity Survey Replication Study, the lifetime prevalence of major depressive disorder (MDD) in the U.S. population is $16.6 \%$ [1]. While not included in the MDD's diagnostic criteria, anxiety is among the three most frequent signs (along with the symptoms of personality disorders and substance abuse) presented by depressive patients [2].

Although easy to overlook in general medical settings, depression and anxiety impose a significant burden on patients with various somatic diseases, and cardiac patients are no exception to the rule. Epidemiological data suggests that MDD affects approximately $17-20 \%$ of those with coronary heart disease (CHD), $16-28 \%$ of myocardial infarction (MI) survivors [3] (with even higher ratios of subclinical depressive syndromes [4]), and $30 \%$ of patients with heart failure (HF) [5].

The negative impact of MDD on the risk of developing CHD and on the disease's subsequent course has become widely acknowledged. It has also been confirmed that depression is a major contributor to increased mortality, morbidity, rehospitalisation rates, reduced health status and functional impairment in patients with congestive heart failure (CHF) [6]. Notably, MDD has been found to be independent risk factor for early-onset cardiovascular diseases (CVD) and CHD-related mortality in a sample of patients below 40 years of age [7].

The following four pathophysiological mechanisms have been posited to account for the link between CVD and MDD: alterations in platelet activity, increased activity of inflam- matory cytokines, decreased heart rate variability (HRV), and hyperactivity of the hypothalamic-pituitary-adrenal axis (implying activation of the sympathetic nervous system) [8].

It should not be forgotten that the CVD-MDD relationship is a mutual one. While discussing the common ground between depression and HF, Nair et al. [9] noticed that depressed patients are less active, often cling to an inadequate diet, have worse compliance with medication, and are more prone to abusing tobacco and alcohol. Thus, such behavioural disturbances may exert deleterious effects on both the course of HF and the patient's self-image, possibly leading to the exacerbation of depression. Also, as heavy smoking has been found to be an independent risk factor for MDD [10], it is worth mentioning that nicotine dependence seems to be a pathogenetic common ground for both depression and CVD.

Given these facts, the aim of this review was to highlight the importance of the accurate diagnosis and treatment of anxiety and depression in patients attending cardiologic facilities.

\section{ANXIETY AND DEPRESSION IN GENERAL MEDICAL SETTINGS}

Two major symptomatic manifestations of anxiety would seem to be of special importance in the realm of somatic medicine: somatoform disorders (somatisation, hypochondria and autonomic dysfunctions observed in the absence of any somatic illness), and somatic anxiety secondary to a medical condition [6].

The most common non-somatic symptom that patients report to physicians is panic anxiety (the basic sign of panic disorder). Panic anxiety is described as an acute episode of anxiety accompanied by feelings of impending doom (imminent myocardial infarction, asthma exacerbation or death). While panic disorder frequently co-occurs with asthma (especially with the severe and aspirin-induced types of the disease) [11], it is worth mentioning that high-trait anxiety is also a common feature of patients with co-morbid heart disease and anxiety disorder - particularly in the course of CHD exacerbation [6].

\footnotetext{
Address for correspondence:

Prof. Dominika Dudek, MD, PhD, Department of Affective Disorders, Department of Psychiatry, Jagiellonian University, Collegium Medicum, ul. Kopernika 21a, 31-501 Kraków, Poland, tel: +48 12 4248703, fax: +48 12 4248745, e-mail: dominika.dudek@poczta.fm

Copyright (C) Polskie Towarzystwo Kardiologiczne
} 
Depression is a serious problem in a variety of medical illnesses. For example, approximately $40 \%$ of subjects with diabetes experience depressed mood and 25\% have clinically significant depression that requires pharmacotherapy. The relationship between mental disorders and diabetes appears mutual, as the risk of developing diabetes is $37 \%$ higher in a group of patients with psychiatric disorders (compared to the general population) [12]. Among subjects with cancer, the prevalence of depression is estimated to be as high as $8-57 \%$ (the exact figure depends on the type and stage of the disease) [13]. Patients with renal failure or liver insufficiency often experience anxiety and depressive disorders, as well as dementia or psychosis [14]. Finally, it is worth mentioning that subjects with autoimmune diseases are also prone to developing various neuropsychiatric syndromes, including anxiety, depression, cognitive disorders, memory impairment and psychosis [15].

\section{DEPRESSION AND ANXIETY IN PATIENTS TREATED FOR CARDIOLOGIC DISEASES}

The question of the relationship between depression and anxiety and CVD is a multi-dimensional one. On the one hand, the findings indicating that depression and CVD share pathophysiological determinants are known, while on the other hand MDD is an independent factor that influences the course of numerous CVD [16]. Furthermore, the application of some methods of treatment for patients with CVD has a significant influence on the risk of anxiety or depression.

\section{Anxiety in patients with cardiovascular diseases}

Though anxiety is probably the most frequent psychopathological symptom in patients who have suffered acute cardiovascular episodes (this is experienced by $70-80 \%$ of patients in this group), it is also a serious problem in those who have chronic forms of CVD. It is estimated that $20-25 \%$ of patients in the latter population experience long-term, persistent anxiety. Among those with HF, anxiety is even more frequent (it is experienced by $25-50 \%$ of patients in this group) [17]. The presence of this symptom impedes patients in their adaptation to the difficult situation produced by the chronic illness and is associated with lower quality of life, greater difficulty in absorbing and acting on medical recommendations, and slower recovery following acute CVD episodes. The anxiety experienced by patients with CVD is a predictor for greater severity of the symptoms of the underlying disease and, as a consequence, a greater level of functional impairment. In assessing the level of anxiety in patients with somatic diseases, particular attention should be paid to the accounts of the patients themselves, as the objective symptoms regarded as 'markers' of anxiety, such as heart rate or blood pressure, are not reliable in patients with acute episodes of CVD [18].

De Jong et al. [19] demonstrated that the level of anxiety experienced by those with recent $\mathrm{MI}$ is on average $44 \%$ greater than in a healthy population. At the same time, the level of anxiety in women was approximately $25 \%$ greater than in men. This finding supplies a further argument in favour of the need for anxiolytic therapy for the patients in this group, as anxiety is a risk factor in the occurrence of $\mathrm{Ml}$ complications (arrhythmias or further episodes of MI) and is also associated with greater mortality. Moreover, the value of this risk is in direct proportion to the severity of the anxiety. The pathogenic basis for the relationship between anxiety and a poor prognosis in $\mathrm{MI}$ is not known. Moser [18] suggests that the physiological (for example, activation of the sympathetic nervous system) and behavioural (for instance, poorer co-operation during treatment) correlates of anxiety could be connected with unsatisfactory therapy results. She also points out that this problem appears to be specific to $\mathrm{MI}$, as the data on the influence of anxiety on the prognosis in other CVDs is ambiguous.

\section{Influence of depression on the course of cardiovascular diseases}

The characteristic feature of MDD in patients with cardiologic diseases is the long-term persistence of its symptoms. Based on a review of the literature, Celano and Huffman [16] found that $50-70 \%$ of patients hospitalised because of acute cardiovascular episodes already met the diagnostic criteria for MDD before the episode, while in patients with stable CHD the symptoms of depression often precede acute decompensated HF by many months (or even years).

The co-occurrence of MDD and CVD significantly affects the results of treatment. It has been shown that patients with $\mathrm{CHD}$ and depression who have had coronary artery bypass graft (CABG) operations achieved poorer functional outcomes, experienced lower quality of life, had faster developing atherosclerosis, and greater rates of re-hospitalisation and mortality [16].

Ample data has been compiled suggesting that the risk of occurrence of further episodes of acute CHD is greater in patients whose depression developed after MI than in patients without depression [16]. However, the conclusion that depression has a negative influence on the prognosis of patients after $\mathrm{MI}$ does not appear surprising: it is now known that not every subtype of MDD is associated with a greater risk of complications in this group of patients. Martens et al. [20] found that — following MI — patients who suffered from depression with somatic/affective symptoms were characterised by reduced left ventricular ejection fraction, experienced further episodes of $\mathrm{MI}$ more often and were at greater risk of death. The occurrence of MDD as manifested by the presence of cognitive/affective symptoms was not associated with these effects. De Jonge et al. [21] discovered that patients suffering from MDD with somatic symptoms had lower HRV, which could lead to worse outcomes in some cases of CVD, including MI. Other factors that could play a significant role in the pathogenesis of 'post heart attack' depression include the increased activity of pro-inflammatory cytokines accompa- 
nying left ventricular dysfunction, and functional impairment resulting from $\mathrm{MI}$ [22].

When considering the relationship between poorer prognosis and the clinical signs of depression, it is worth remembering that this is not only found with $\mathrm{MI}$ but also with other CVDs. According to Celano and Huffman [16], the following psychiatric factors of prognosis are especially adverse in patients suffering from these illnesses: treatment-resistant depression, depression accompanied by anxiety, depression with significant anhedonia and the depression that accompanies type $\mathrm{D}$ personality traits (expressed by negative affect and social inhibition).

Some researchers have pointed to the existence of 'arrhythmogenic properties of depression'. This conclusion was drawn based on evidence that individuals with MDD who have experienced MI have a higher risk of death due to ventricular arrhythmias. It is also known that in patients with atrial fibrillation (AF) who have undergone cardioversion, the risk of recurrence of this illness is greater in the case of co-occurrence with MDD [16].

It would appear, moreover, that depression is an adverse prognostic factor in some populations of patients with arrhythmias. Frasure-Smith et al. [23] demonstrated that patients with $\mathrm{HF}$ and AF who experienced mild or significant MDD were at greater risk of death from cardiovascular causes than patients without depression.

The co-occurrence of depression leads to significantly worse treatment results for patients with HF. The results of a meta-analysis conducted by Rutledge et al. [24] suggest that the combined risk of repeated cardiovascular episodes, or of death, in patients with MDD and HF is approximately twice as great as in patients who have HF but are unaffected by depression. These patients are also hospitalised more often and make more visits to hospital accident and emergency departments. Jiang et al. [25] found that the severity of symptoms of depression was a differentiating factor in the risk of death in patients with HF. Jiang's team observed that patients whose severity of depression corresponded with a score of $\geq 19$ on the Beck Depression Inventory (BDI) were subjected to a risk of death as much as $83 \%$ greater compared to patients who had scores of $<5$ on the same scale. It is significant that MDD is not only one of the possible outcomes of HF, but can also be a factor that leads to this illness. The authors gathered their evidence for this thesis by studying patients with CHF. As the studies proceeded, it was observed that depression acts in synergy with other risk factors for the development of CHF [16].

\section{Influence of specific therapeutic methods employed in patients with cardiovascular diseases on the risk of depression or anxiety}

Numerous studies have been devoted to the occurrence of depression in individuals being treated for CVDs (both conservatively and with the use of invasive methods).
Probably the largest number of studies analysing the relationship between the use of 'cardiologic' medicines and the risk of the development of depression concern beta-blockers. Despite the widespread opinion that these medicines have depressionogenic potential, it would appear that the greater risk of occurrence of MDD is mainly associated with patients who take the most lipophilic (i.e. most easily breaching the blood-brain barrier) of beta-blockers: propranolol. The data that is currently available does not confirm that there exists a 'depressionogenic group effect' of beta-blockers. However, because the use of lipophilic beta-blockers in individuals with a family history of MDD can increase the risk of occurrence of depression, it is necessary to pay particular attention to changes in mental state in this group of patients with CVD. Yet, taking into account that the use of these medicines significantly reduces morbidity and mortality in patients with CVD, the results of using beta-blockers - even in individuals from groups at risk of MDD - would appear beneficial [26]. It is worth remembering that taking such medicines as interferon alpha (whose use is associated with a risk of occurrence of MDD of $20-40 \%$ [27]), angiotensin-converting enzyme inhibitors, thiazide diuretics, calcium channel blockers, corticosteroids, anticonvulsants and certain nonsteroidal anti-inflammatory drugs (especially indometacin) may also lead to the occurrence of symptoms of depression [28].

The occurrence of the symptoms of depression or anxiety is a significant problem in individuals with HF who have received implantable cardioverter-defibrillators (ICD). Freedenberg et al. [29] noted that though employing ICDs undoubtedly contributed to the reduction of morbidity in patients with HF, their mental state often left much to be desired, as the symptoms of depression were present in 24-33\% of them and anxiety was experienced by $24-87 \%$ of patients with HF and ICDs.

The most important risk factors for the occurrence of these symptoms are being young, being female and frequent ICD discharges [30].

The authors cited above emphasise that one of the conditions for the proper care of patients with ICDs is the prevention of the occurrence of anxiety and depression. It is necessary to work towards the maximum stabilisation of the clinical states of these patients and - as a consequence - limit the number of ICD discharges. Screening for anxiety or depression in patients who are to undergo ICD therapy can make it possible to identify those who require psychological or psychiatric care. Where patients who already have ICDs are concerned, it is necessary to assess the severity of the symptoms of depression and anxiety every six months [29].

Anxiety very frequently accompanies patients who are receiving revascularisation procedures. According to Trotter et al. [31], this symptom is experienced by $24-72 \%$ of individuals who undergo percutaneous coronary intervention ( $\mathrm{PCl}$ ). Trotter's team noted, however, that the level of anxiety before PCI 
is usually not very high and that it decreases continuously over time following the procedure. Those who experience chest pain after the procedure, and those who have undergone $\mathrm{PCl}$ for the first time, are at risk of particularly severe anxiety. Taking anxiolytics or antidepressants is a further risk factor for the occurrence of symptoms of anxiety before PCl.

In research that included patients who had undergone CABG, Pawlak et al. [32] found a negative correlation between age and the intensity of anxiety experienced following the procedure, and a positive correlation between the severity of the anxiety and the level of symptoms of depression. Pawlak's team also found that the anxiety experienced by women following $\mathrm{CABG}$ is more intense than that of men.

Finally, it is worth mentioning that depression is one of the common complications of cardiac surgery [33]. Freedland et al. [34] reported that full-blown MDD episodes develop in approximately $20 \%$ of individuals who undergo CABG procedures. Patients who experience perioperative depression more frequently experience surgical complications, require more time for full convalescence and have a poorer quality of life. Moreover, the subjective sense of the presence of cognitive dysfunction is more intense in them than in more tranquil individuals, and they are also at greater risk of cardiovascular episodes or death.

\section{DIAGNOSTIC DIFFICULTIES}

Even though MDD occurs very often in individuals with cardiologic diseases, it often escapes the attention of doctors [16]. There is data suggesting that depression is diagnosed in only $25 \%$ of patients with co-occurring CHD and MDD, while only $12.5 \%$ of these patients receive adequate antidepressive therapy [3]. The non-specificity of the depressive symptomatology observed in this population of patients (who often suffer from a sense of fatigue, a loss of appetite, weakened libido, and a general feeling of poor health and spirit) and the domination of somatic symptoms (often the result of what is known as catastrophic interpretation of body sensations — characteristic for MDD, as well as for panic disorder [35]), mean depressive symptoms of negligible or mild intensity are often interpreted as signs of poor general medical condition, or as adverse effects of the medicines being used. Furthermore, patients often do not report symptoms of depression in the belief that doctors are interested only in somatic symptoms [6].

Assessment of the mental state of the patient should be a permanent feature of clinical examination - including for doctors who are not psychiatrists [6]. This principle was adopted in the guidelines produced by experts at the American Heart Association (AHA), who stated that screening for depression is necessary for all patients with CHD [36].

When examining patients with suspected depressive disorders, particular attention should be paid to the presence of depressive cognitive styles (arranged in the Beck triad of pessimistic thoughts about oneself, the world and the future), as well as to suicidal ideations and statements from patients referring to low quality of life and sense of guilt $[6,37]$. These symptoms often obscure the negative symptoms of depression, which are depressed mood, anhedonia (reduction or complete loss of the capacity to experience pleasure), and increased fatigue or loss of energy [38]. Because distinguishing between MDD and the 'poor spirit' experienced by individuals with serious somatic diseases can be difficult, it is worth remembering that the major symptom of depression in individuals with general medical conditions is often anhedonia, while those who are demoralised usually speak of feelings of helplessness and disempowerment [28].

According to the AHA experts [36], the basic tool facilitating the identification of MDD in individuals with cardiologic diseases is the Patient Health Questionnaire-9 (PHQ-9) [39]. There are also other scales that can be used, such as the Hospital Anxiety Depression Scale (HADS) [40], the Geriatric Depression Scale (GDS) [41] and the 'classic' depression-diagnosis tools: BDI, the Montgomery-Asberg Depression Rating Scale (MADRS) and the Hamilton Rating Scale for Depression (HDRS) [42]. Conducting neuropsychological diagnostics (in co-operation with a clinical psychologist) in individuals who have had cardiac surgery may help in differentiating the depressive feeling of cognitive impairment from 'real' cognitive disorders [43, 44].

In discussing the various tools used in the diagnosis of depression, it is necessary to remember that the 'tool' with perhaps the greatest sensitivity and specificity with respect to depressive disorders in individuals with chronic diseases is the question: 'Are you depressed?' [28, 45]. This seemingly trivial observation is all the more important in that the results of all the systematic reviews with meta-analyses have suggested that some of the universally applied tests designed to facilitate diagnosis of MDD in patients with CVD (BDI, HDRS, HADS) have unsatisfactory psychometric properties [46, 47].

\section{TREATMENT OF ISCHAEMIC HEART DISEASE AND DEPRESSION}

The small quantity of data originating from randomised controlled trials and the necessity for further research into the cause and effect relationship between CHD and MDD explain why an algorithm for the therapy of patients suffering from these disorders has not yet been developed. The present guidelines are composed mainly of expert opinions, which means that their reliability is limited [48].

Based on the results of literature reviews, Ramasubbu et al. [49] and Mavrides and Nemeroff [8] have suggested that in the process of treating patients with depression and CHD, it is necessary to employ both pharmacological and psychosocial interventions. The results of most randomised controlled trials (SADHART, CREATE, ENRICHD, MIND-IT) have indicated that selective serotonin reuptake inhibitors (SSRI) are the safest therapeutic option for patients in the group under discussion. 
They produce few adverse effects and, compared to a placebo, effectively reduce the severity of depressive symptoms (though it is worth mentioning that the results of the SADHART-CHF randomised controlled trials lead to less optimistic conclusions regarding the effectiveness of SSRI). Because most of the promising scientific data on the effectiveness and safety of employing antidepressants in individuals with CHD and MDD concerns sertraline, Mavrides and Nemeroff [8] deemed it to be the first-choice antidepressant for these patients. Other SSRIs, such as fluoxetine, paroxetine, citalopram and escitalopram, would appear equally effective. However, before making the decision to use one of them, it is necessary to conduct a risk analysis for the occurrence of drug interactions (the risk is particularly great in the case of fluoxetine used together with propranolol or metoprolol, paroxetine or fluvoxamine used with IC class antiarrhythmic medicines or theophylline, and also citalopram with digitalis) [8, 50].

It is important to remember that combined use of antidepressants and antipsychotics is a significant risk factor of sudden cardiac death in patients undergoing acute coronary events [51].

When using tricyclic antidepressants (amitriptyline, doxepin or clomipramine) it is important to be aware of the risk of orthostatic hypotension - especially in patients with left-ventricular impairment [50]. While there is a lack of data on the effectiveness and safety of the long-term use of tricyclic antidepressants (TCA) in patients with CHD and MDD, it is necessary to remember their pharmacodynamics renders them similar to class I antiarrhythmic drugs according to the Vaughan Williams classification. Acting as inhibitors of the sodium channels and also as inhibitors of the fast potassium channels, they can prolong the QT interval, whose effect in turn can be potentially lethal arrhythmias (for example, torsade de pointes or ventricular fibrillation) [8]. In this way, dangerous interactions of TCAs with antiarrhythmic medicines can occur. Although it would appear that TCAs can be safely used in patients with mild intra-ventricular conduction abnormalities, they are contra-indicated for patients with atrioventricular block, right bundle branch block, cardiac arrhythmia, and in the period directly following an $\mathrm{MI}$ [50].

Data on the subject of the effectiveness and safety of using other antidepressants in patients with CHD and MDD is a great deal more scarce, yet it would seem that in this group of patients bupropion could be used with satisfactory outcomes. Although the authors of the MIND-IT research did not find that mirtazapine had an advantage over a placebo in terms of reducing the severity of depressive symptoms in patients in the post heart attack period, they did discover that individuals who had not had any therapeutic response from using antidepressants were at a significantly greater risk of a further cardiovascular episode [8].

Of the non-pharmacological interventions that can be employed in individuals with CHD and MDD, the implemen- tation of cognitive-behavioural therapy (CBT), interpersonal therapy or problem-solving therapy is recommended [49].

Some data suggests that the application of CBT leads to a reduction in mortality in patients with $\mathrm{CHD}$ and MDD [8]. The results of observational studies suggest that exercise training can limit the severity of depressive symptoms [52]. It would thus appear that patients participating in cardiologic rehabilitation programmes have the opportunity to benefit not only from improvements in the functioning of their cardiovascular systems, but also from reductions in the suffering caused by depression.

\section{SUMMARY}

The co-occurrence of depression and CVD is a serious but underestimated clinical problem. The presence of depressive disorders exerts a negative influence on the results of treatment of patients with CVD.

It is necessary to conduct screening for depression in all patients with cardiac diseases, while the appropriate pharmacological and psychosocial therapies should be applied in patients confirmed as having depressive disorders.

\section{Conflict of interest: none declared}

\section{References}

1. Kessler RC, Berglund P, Demler O et al. Lifetime prevalence and age-of-onset distributions of DSM-IV disorders in the National Comorbidity Survey Replication. Arch Gen Psychiatry, 2005; 62: 593-602.

2. Schoevers RA, Van HL, Koppelmans V et al. Managing the patient with co-morbid depression and an anxiety disorder. Drugs, 2008; 68: 1621-1634.

3. Dudek D, Siwek M. Współistnienie chorób somatycznych i depresji. Psychiatria, 2007; 4: 17-24.

4. Thombs BD, Bass EB, Ford DE et al. Prevalence of depression in survivors of acute myocardial infarction. J Gen Intern Med, 2006; 21: 30-38.

5. Diez-Quevedo C, Lupon J, Gonzalez B et al. Depression, antidepressants, and long-term mortality in heart failure. Int J Cardiol, 2012 [Epub ahead of print 2012/04/18].

6. Dudek D, Sobanski JA. Mental disorders in somatic diseases: psychopathology and treatment. Pol Arch Med Wewn, 2012; 122: 624-629.

7. Shah AJ, Veledar E, Hong Y et al. Depression and history of attempted suicide as risk factors for heart disease mortality in young individuals. Arch Gen Psychiatry, 2011; 68: 1135-1142.

8. Mavrides N, Nemeroff C. Treatment of depression in cardiovascular disease. Depress Anxiety, 2013 [Epub ahead of print 2013/01/08].

9. Nair N, Farmer C, Gongora E, Dehmer GJ. Commonality between depression and heart failure. Am J Cardiol, 2012; 109: 768-772.

10. Khaled SM, Bulloch AG, Williams JV et al. Persistent heavy smoking as risk factor for major depression (MD) incidence: evidence from a longitudinal Canadian cohort of the National Population Health Survey. J Psychiatr Res, 2012; 46: 436-443.

11. Potoczek A. Związek mechanizmów obronnych osobowości z nasileniem objawów zespołu lęku napadowego i depresji u kobiet i mężczyzn z astmą cieżką i trudną oraz astmą aspirynową. Psychiatr Pol, 2011; 45: 21-33.

12. Duda-Sobczak A, Wierusz-Wysocka B. Cukrzyca a choroby psychiczne. Psychiatr Pol, 2011; 45: 589-598.

13. Jaeschke R. Ból i depresja w chorobach nowotworowych. In: Dudek D ed. Ból i depresja. Termedia, Poznań 2011: 103-118. 
14. Makara-Studzińska M, Książek P, Koslak A et al. Rozpowszechnienie zaburzeń depresyjnych wśród pacjentów ze schyłkową niewydolnością nerek. Psychiatr Pol, 2011; 45: 187-195.

15. Celińska-Lowenhoff M, Musiał J. Zaburzenia psychiczne w chorobach autoimmunologicznych: problemy diagnostyczno-terapeutyczne. Psychiatr Pol, 2012; 46: 1029-1042.

16. Celano CM, Huffman JC. Depression and cardiac disease: a review. Cardiol Rev, 2011; 19: 130-142.

17. Hallas CN, Wray J, Andreou P, Banner NR. Depression and perceptions about heart failure predict quality of life in patients with advanced heart failure. Heart Lung, 2011; 40: 111-121.

18. Moser DK. "The rust of life": impact of anxiety on cardiac patients. Am J Crit Care, 2007; 16: 361-369.

19. De Jong MJ, Chung ML, Roser LP et al. A five-country comparison of anxiety early after acute myocardial infarction. Eur J Cardiovasc Nurs, 2004; 3: 129-134.

20. Martens EJ, Hoen PW, Mittelhaeuser M et al. Symptom dimensions of post-myocardial infarction depression, disease severity and cardiac prognosis. Psychol Med, 2010; 40: 807-814.

21. de Jonge P, Mangano D, Whooley MA. Differential association of cognitive and somatic depressive symptoms with heart rate variability in patients with stable coronary heart disease: findings from the Heart and Soul Study. Psychosom Med, 2007; 69: 735-739.

22. de Jonge P, Denollet J, van Melle JP et al. Associations of type-D personality and depression with somatic health in myocardial infarction patients. J Psychosom Res, 2007; 63: 477-482.

23. Frasure-Smith N, Lesperance F, Habra M et al. Elevated depression symptoms predict long-term cardiovascular mortality in patients with atrial fibrillation and heart failure. Circulation, 2009; 120 134-140.

24. Rutledge T, Reis VA, Linke SE et al. Depression in heart failure a meta-analytic review of prevalence, intervention effects, and associations with clinical outcomes. J Am Coll Cardiol, 2006; 48 : 1527-1537.

25. Jiang W, Kuchibhatla M, Clary GL et al. Relationship between depressive symptoms and long-term mortality in patients with heart failure. Am Heart J, 2007; 154: 102-108.

26. Verbeek DE, van Riezen J, de Boer RA et al. A review on the putative association between beta-blockers and depression. Heart Fail Clin, 2011; 7: 89-99.

27. Loftis JM, Patterson AL, Wilhelm CJ et al. Vulnerability to somatic symptoms of depression during interferon-alpha therapy for hepatitis C: a 16-week prospective study. J Psychosom Res, 2013; 74: 57-63.

28. Rackley S, Bostwick JM. Depression in medically ill patients. Psychiatr Clin North Am, 2012; 35: 231-247.

29. Freedenberg V, Thomas SA, Friedmann E. Anxiety and depression in implanted cardioverter-defibrillator recipients and heart failure: a review. Heart Fail Clin, 2011; 7: 59-68.

30. Thomas SA, Friedmann E, Kao CW et al. Quality of life and psychological status of patients with implantable cardioverter defibrillators. Am J Crit Care, 2006; 15: 389-398.

31. Trotter R, Gallagher R, Donoghue J. Anxiety in patients undergoing percutaneous coronary interventions. Heart Lung, 2011; 40 185-192.

32. Pawlak A, Krejca M, Janas-Kozik M et al. Ocena lęku i depresji w okresie okołooperacyjnym u pacjentów poddawanych rewaskularyzacji mięśnia sercowego. Psychiatr Pol, 2012; 46: 63-74.

33. Szwed K, Bieliński M, Drożdż W et al. Zaburzenia funkcjonowania poznawczego po zabiegach kardiochirurgicznych. Psychiatr Pol, 2012; 46: 473-482.

34. Freedland KE, Skala JA, Carney RM et al. Treatment of depression after coronary artery bypass surgery: a randomized controlled trial. Arch Gen Psychiatry, 2009; 66: 387-396.

35. Potoczek A. Ogólne różnice w nasileniu katastroficznej interpretacji doznań somatycznych oraz jej szczegółowy związek z nasileniem objawów zespołu lęku napadowego i depresji u ko- biet i mężczyzn z astmą ciężką i trudną oraz astmą aspirynową. Psychiatr Pol, 2011; 45: 481-493.

36. Lichtman JH, Bigger JT, Jr., Blumenthal JA et al. Depression and coronary heart disease: recommendations for screening, referral, and treatment: a science advisory from the American Heart Association Prevention Committee of the Council on Cardiovascular Nursing, Council on Clinical Cardiology, Council on Epidemiology and Prevention, and Interdisciplinary Council on Quality of Care and Outcomes Research: endorsed by the American Psychiatric Association. Circulation, 2008; 118: 1768-1775.

37. Ramasubbu R, Beaulieu S, Taylor VH et al. The CANMAT task force recommendations for the management of patients with mood disorders and comorbid medical conditions: diagnostic, assessment, and treatment principles. Ann Clin Psychiatry, 2012; 24: 82-90.

38. Dudek D, Siwek M, Wysocki H. Depresja a choroba niedokrwienna serca. In: Podolec P ed. Podręcznik Polskiego Forum Profilaktyki. Tom II. Medycyna Praktyczna, Kraków 2010: 503-510.

39. Tomaszewski K, Zarychta M, Bieńkowska A et al. Walidacja polskiej wersji językowej Patient Health Questionnaire-9 w populacji hospitalizowanych osób starszych. Psychiatr Pol, 2011; 45: 223-233.

40. Wichowicz HM, Wieczorek D. Badanie przesiewowe depresji poudarowej z użyciem Hospital Anxiety and Depression Scale (HADS). Psychiatr Pol, 2011; 45: 505-514.

41. Albiński R, Kleszczewska-Albińska A, Bedyńska S. Geriatryczna Skala Depresji (GDS). Trafność i rzetelność różnych wersji tego narzędzia: przegląd badań. Psychiatr Pol, 2011; 45: 555-562.

42. Davidson KW, Kupfer DJ, Bigger JT et al. Assessment and treatment of depression in patients with cardiovascular disease: National Heart, Lung, and Blood Institute Working Group Report. Psychosom Med, 2006; 68: 645-650.

43. Talarowska M, Florkowski A, Zboralski K, Galecki P. Wykonanie testu pamięci wzrokowej Bentona oraz Wzrokowo-Motorycznego Testu Gestalt Lauretty Bender przez osoby z depresją i organicznymi zaburzeniami depresyjnymi. Psychiatr Pol, 2011; 45: 495-504.

44. Talarowska M, Zboralski K, Mossakowska-Wojcik J, Galecki P. Wykonanie Testu Laczenia Punktów przez osoby z depresją i organicznymi zaburzeniami depresyjnymi. Psychiatr Pol, 2012; 46: 273-282

45. Chochinov HM, Wilson KG, Enns M, Lander S. "Are you depressed?" Screening for depression in the terminally ill. Am J Psychiatry, 1997; 154: 674-676.

46. Thombs BD, de Jonge P, Coyne JC et al. Depression screening and patient outcomes in cardiovascular care: a systematic review. JAMA, 2008; 300: 2161-2171.

47. Thombs BD, Roseman M, Coyne JC et al. Does evidence support the American Heart Association's recommendation to screen patients for depression in cardiovascular care? An updated systematic review. PLoS One, 2013; 8: e52654.

48. Jaeschke R, Siwek M, Brozek J, Brudkiewicz P. Badania z randomizacją w psychiatrii. Psychiatr Pol, 2012; 46: 109-121.

49. Ramasubbu R, Taylor VH, Samaan Z et al. The Canadian Network for Mood and Anxiety Treatments (CANMAT) task force recommendations for the management of patients with mood disorders and select comorbid medical conditions. Ann Clin Psychiatry, 2012; 24: 91-109.

50. Dudek D, Siwek M. Leczenie zaburzeń depresyjnych u pacjentów z chorobami układu sercowo-naczyniowego. In: Podolec P ed. Podręcznik Polskiego Forum Profilaktyki. Tom II. Medycyna Praktyczna, Kraków 2010: 547-554.

51. Honkola J, Hookana E, Malinen S et al. Psychotropic medications and the risk of sudden cardiac death during an acute coronary event. Eur Heart J, 2012; 33: 745-751.

52. Wang JT, Hoffman B, Blumenthal JA. Management of depression in patients with coronary heart disease: association, mechanisms, and treatment implications for depressed cardiac patients. Expert Opin Pharmacother, 2011; 12: 85-98. 